Przegląd Prawa Konstytucyjnego

--ISSN 2082-1212--------

DOI 10.15804/ppk.2016.04.16

$-\mathrm{Nr} 4(32) / 2016$

\title{
Sprawozdanie
}

\section{Konferencja Krajowej Rady Sądownictwa, Granice niezawistości sędziów i niezależności sądów?, Warszawa, 18-19 stycznia 2016 r.}

W dniach 18-19 stycznia 2016 r. Krajowa Rada Sądownictwa zorganizowała konferencję Granice niezawisłości sędziów i niezależności sądów?, która odbyła się w Warszawie w siedzibie organizatora. W wydarzeniu tym wzięli udział polscy sędziowie, eksperci o uznanym dorobku naukowym i zawodowym oraz znamienici goście z zagranicy.

Uroczyste otwarcie konferencji rozpoczęło się powitaniem gości przez sędziego SN Dariusza Zawistowskiego, przewodniczącego KRS. Sędzia w swoim wystąpieniu podkreślił wagę spotkania, aktualność tematu, a także zarysował tło merytoryczne do dalszych dyskusji. Następnie rozpoczęły się wystąpienia otwierające zaproszonych prelegentów. Jako pierwsza głos zabrała prof. dr hab. SSN Małgorzata Gersdorf, pierwszy prezes SN. W odczuciu prelegentki mamy do czynienia z kolejnym kryzysem demokracji, a władza sądownicza stała się pierwszą ofiara sporu. Judykatywa uznana została błędnie za skorumpowaną grupę, zależną partyjnie, utrudniającą rządy. Podkreśliła, że immunitet sędziowski jest w interesie obywateli, a niezawisłość to zgodność z prawem i własnym sumieniem, a nie sumieniem zbiorowości czy aktualnego obozu rządowego. Prócz tego wyraziła dezaprobatę w stosunku do nadzoru administracyjnego nad sądownictwem sprawowanego przez ministra sprawiedliwości. Jako drugi głos zabrał Jerzy Stępień, prezes TK w stanie spoczynku. Mówca zauważył, że mamy do czynienia $\mathrm{z}$ fenomenem, bowiem ułaskawienie osoby nieprawomocnie skazanej jest 
przekroczeniem uprawnień przez prezydenta. Zdarzenie to jest sygnałem, że rozpoczyna się w Polsce nowa procedura i że jest pewna grupa polityków stawiająca się ponad prawem, a większość rządowa nie myśli o kompromisach. Jako trzeci głos zabrał dr Bohdan Zdziennicki, były prezes TK. Przypomniał, iż historia zna już instytucję „sędziów ludowych”, bowiem to właśnie Trybunał Ludowy III Rzeszy w części składał się z nieprawników. Zauważył, że nie jest to wyłącznie fatalna analogia historyczna. Instytucja ta bezpośrednio godziłaby w niezawisłość sędziów i istotę wymiaru sprawiedliwości. Jako czwarta głos zabrała prof. dr hab. Ewa Łętowska, Sędzia TK w stanie spoczynku. Podkreśliła, że ani praktyka sądowa ani praktyka TK nie doprowadziły do wyjaśnienia jak działa mechanizm trójpodziału władzy. Władza sędziowska to władza rozproszona nad prawem, wypełniająca luki, opierająca się na umiejętnej wykładni i stanowieniu reguł stosowania prawa w oparciu o sumienie sędziów wzbogacone wiedzą, a nie ideologią. Współdziałanie różnych organów władzy jest pojęciem idealizującym. W praktyce polega to na testowaniu (wyrywaniu) władzy, a niedoświadczenie polityków prowadzi do kryzysu. Natomiast prof. dr hab. Mirosław Wyrzykowski, Sędzia TK w stanie spoczynku zauważył, iż obecnie mamy do czynienia ze stanem klęski demokratycznego państwa prawnego. Uchwalane są ustawy, które uniemożliwiają ochronę konstytucyjną prawa, tak więc TK powinien podejmować rozstrzygnięcia bezpośrednio w oparciu o ustawę zasadniczą. Następnie swoje wystąpienie przedstawił sędzia SR Łukasz Piebiak, Podsekretarz Stanu w Ministerstwie Sprawiedliwości, który zauważył, że gdy chodzi o nadzór administracyjny ministerstwa nad sądami, to w codziennym funkcjonowaniu istotniejszą rolę nadal odgrywają prezesi sądów, jednak minister powinien korygować działania sędziowskie budzące sprzeciw w społeczeństwie. Radca prawny Dariusz Sałajewski, prezes Krajowej Rady Radców Prawnych w swojej wypowiedzi wyszczególnił, że reprezentowane przez niego środowisko chce niezależności sądów i niezawisłości sędziów dla swoich klientów, bo to oni są adresatami tych zasad. Na koniec głos zabrał adwokat Andrzej Zwara, prezes Naczelnej Rady Adwokackiej, który stwierdził, że konflikt między fenomen procesu politycznego a autonomiczną wartością prawa istnieje już od paru lat. Dla władzy sądowniczej i adwokatów królem jest prawo i etyka, a sędziowie mają narzędzia do zachowania niezawisłości - jest to prawo Unii Europejskiej i własne sumienie. 
Pierwszy panel dyskusyjny, Perspektywa europejska niezawisłości sędziów i niezależności sądów, moderował sędzia SR dr Grzegorz Borkowski, szef Biura KRS. Jako pierwszy głos zabrał prof. dr Gerhard Holzinger, prezes Sądu Konstytucyjnego w Austrii. Niezależność sądownictwa to najistotniejszy element rządów prawa - rozpoczął swoje wystąpienie. Nie bez przyczyny po II wojnie światowej w Europie w państwach przechodzących z dyktatury do demokracji powstawały sądy konstytucyjne, bowiem rządy większości są do zniesienia, jeżeli realizuje się je zgodnie z prawem. Co więcej, spory toczone przed sądami konstytucyjnymi mają charakter nie tylko prawny, ale także polityczny, stąd sądy konstytucyjne działają na styku obu tych dziedzin. Następnie głos zabrał Lord Geoffrey Vos, przewodniczący ENCJ. Sędziowie muszą być niezależni od politycznego wpływu i grup nacisku w podejmowaniu decyzji, to w ich gestii leży rozstrzyganie spraw między państwem a jednostką - podkreślił. Ponadto sędziowie muszą być zaangażowani w prace nad zmianą ustaw dotyczących judykatywy oraz powinni być mianowani wyłącznie na podstawie kryteriów merytorycznych. Natomiast, Orlando Afonso, sędzia SN - były przewodniczący MEDEL i CCJE podkreślił, że sędziowie potrzebują niezawisłości od wszelkich władz, również od władzy nielegitymowanej i od samej władzy sądowniczej w ramach wewnętrznej hierarchii. Niezależność i legitymacja mają bowiem to samo źródło - przepisy konstytucji. To sędzia decyduje co jest prawem, a co jest przeciwko prawu, nie jest on przeciwko nikomu, jest badaczem faktów i prawa. Należy wierzyć, że sędzia jest kompetentny, etyczny, godny zaufania, a jeżeli zachowuje się niezgodnie z przyjętymi normami, to jego niezawisłość nie gwarantuje mu pozostania na piastowanym urzędzie. Kolejno swój referat wygłosił prof. Vigintasa Višinskis, sędzia SA Republiki Litwy, członek Rady Sądownictwa. W swoim wystąpieniu prelegent podkreślił, że na Litwie Sąd Konstytucyjny cieszy się sporym poszanowaniem, MS zatwierdza wyłącznie roczne plany szkoleń dla sędziów, a każdorazowy projekt prawny dotyczący danej instytucji musi być jej przedstawiony do zaopiniowania. Następnie wystąpił Horaţius Dumbravă - sędzia SA, członek Najwyższej Rady Sądownictwa Rumunii, który w swoim wystąpieniu podkreślił, że niezależność judykatywy jest warunkiem praworządności, ponieważ nie jest to prerogatywa sędziowska. W referacie wyraził swoje zaniepokojenie obecną sytuacją w Rumunii. Na temat niezależności sądownictwa w Norwegii swój referat 
wygłosił Wiggo Storhaug Larssen, sędzia SA Gulating w Bergen. Zaprezentowane przez niego wnioski wskazały, iż poziom niezależności sądownictwa w krajach skandynawskich, zgodnie z raportem ENCJ z 2015 r., plasuje te kraje w czołówce rankingu.

Drugi panel dyskusyjny Perspektywa krajowa niezawisłości sędziów i niezależności sądów - ujęcie konstytucyjne, moderował sędzia Janusz Drachal, wiceprezes NSA. Pierwszy wystąpił prof. dr hab. Lech Garlicki, UW, sędzia TK w stanie spoczynku, były sędzia ETPCz, w którego opinii, przerwanie panującego kryzysu konstytucyjnego możliwe jest poprzez afirmacyjne odczytywanie Konstytucji RP. Według niego konieczne jest odnalezienie środków, które staną na straży hierarchii źródeł prawa w Polsce. Dalej głos zabrał dr Adam Bodnar, Rzecznik Praw Obywatelskich. Prelegent zauważył, że przeciętny człowiek nie rozumie, czym jest niezawisłość sędziowska i niezależność sądów, stąd należy uzmysłowić społeczeństwo, jak definiuje się te pojęcia, jakie jest ich zastosowanie w codziennej pracy sędziego, a także jakie są konsekwencje ich braku. Następnie głos zabrał dr hab. Ryszard Piotrowski z UW, który podkreślił, że środowisko sędziowskie nie doceniało istoty niezależności i niezawisłości, dopóki nie podejmowane były próby ich ograniczenia. Ponadto zwrócił uwagę na ogólne przyzwolenie dla aktywności władzy ustawodawczej w zakresie regulacji ustrojowej sądownictwa. Według prelegenta połączenie urzędu MS z Prokuratorem Generalnym sprawi, że funkcjonowanie powyższych zasad będzie iluzoryczne.

Trzeci panel dyskusyjny Perspektywa krajowa niezawisłości sędziów i niezależności sądów - ujęcie etyczne. Moderatorem była sędzia SN, a zarazem członek KRS, Katarzyna Gonera. Jako pierwszy wystąpił sędzia SN, były przewodniczący KRS, Krzysztof Strzelczyk, który podkreślił, że pełnienie urzędu sędziego to nie same prawa, ale i obowiązki. Wskazał na istotę zachowania sędziego w sferze prywatnej i zawodowej. Z dezaprobatą odniósł się do powoływania wydziałów zajmujących się postępowaniem dyscyplinarnym sędziów. Następnie głos zabrał sędzia SN, były przewodniczący KRS, Antoni Górski. Prelegent przypomniał zgromadzonym, jak szkoleni byli sędziowie za początków jego kariery, podkreślając różnice w obecnie funkcjonującym modelu. W dalszej kolejności prof. dr hab. Andrzej Mączyński, sędzia TK w stanie spoczynku zwrócił uwagę, że dla przeciętnego obywatela niezawisłość sędziego oznacza jego bezkarność i brak jakiejkolwiek odpowiedzialności. Ostatni referat zaprezentował dr Paweł Skuczyński z UW, 
który wskazał na istotę zasad niezawisłości, niezależności i bezstronności. Zauważył, że istnieje problem relacji między niezawisłością sędziowską a możliwością krytyki przez sędziów poczynań pozostałych władz.

Drugiego dnia przedstawione zostały wyniki badań empirycznych. Panel moderował sędzia SO, wiceprzewodniczący KRS, Krzysztof Wojtaszek. Jako pierwszy wystąpił sędzia SR, członek KRS, Sławomir Pałka, który zaprezentował raport Europejskiej Sieci Rad Sądownictwa (ENCJ) z roku 2015. Respondentami ankiety byli sędziowie - w badaniu udział wzięło 5878 sędziów z 20 krajów, w tym 621 sędziów z Polski. Przytłaczająca większość respondentów deklarowała, że nie była poddana niewłaściwej presji w celu uzyskania konkretnego rozstrzygnięcia sprawy. Badania wykazały, iż procedury dyscyplinarne i podział spraw nie miały wpływu na niezawisłość sędziów, w przeciwieństwie do wpływu mediów, zmian w warunkach pracy czy presji na załatwienie spraw w określonym czasie. Następny mówca sędzia SR, szef Biura KRS, dr Grzegorz Borkowski przedstawił pokrótce 18 opinii Rady Konsultacyjnej Sędziów Europejskich (CCJE), które dotyczyły m.in. kwestii finansowania, regulacji etycznych, szkoleń, powoływania sędziów, procedur. Natomiast dr hab. Anna Machnikowska, prof. UG, zaprezentowała przeprowadzone przez siebie badanie ankietowe dotyczące niezawisłości sądownictwa wśród sędziów sądów powszechnych w latach 2015-2016. Respondenci wskazali, że czynnikami ograniczającymi niezawisłość są: działania MS, nadmierne obciążenie sprawami w referacie oraz sposób postrzegania przez media. Ostatnie wystąpienie należało do członka zarządu Instytutu Prawa i Społeczeństwa (INPRIS), Grzegorza Wiaderka, który zaprezentował zagadnienie Niezależność sq̨downictwa a działalność organizacji obywatelskich. W swoim referacie postulował współpracę, interakcję, komunikację judykatywy i organizacji obywatelskich.

Przebieg obrad utwierdził organizatora w przekonaniu o tym, jak aktualna $\mathrm{i}$ istotna jest podniesiona problematyka, nie tylko dla środowiska sędziowskiego, ale także akademickiego, adwokackiego, radcowskiego oraz organizacji pozarządowych. Rezultatem dwudniowych obrad będzie publikacja pokonferencyjna. Ponadto uzgodniono, że niektóre z zagadnień powinny stać się przedmiotem szerszej debaty na kolejnej konferencji.

Elżbieta Gudowska-Natanek, Katarzyna Kuś 